\title{
NEUROTOXIC ACTIVITY AND ULTRASTRUCTURAL CHANGES IN MUSCLES CAUSED BY THE BROWN WIDOW SPIDER Latrodectus geometricus VENOM
}

\begin{abstract}
SUMMARY
Brown widow spider (Latrodectus geometricus) venom (BrWSV) produces few local lesions and intense systemic reactions such as cramps, harsh muscle pains, nausea, vomiting and hypertension. Approximately 16 protein bands under reducing conditions and $\sim 14$ bands under non-reducing conditions on a $12.5 \%$ sodium dodecyl sulfate-polyacrylamide gel electrophoresis were observed. Neurotoxic clinical manifestations were confirmed in vivo, while proteolytic activity was demonstrated on gelatine film. Severe ultrastructural damages in mice skeletal muscles were observed at 3, 6, 12 and $24 \mathrm{~h}$ postinjection with at total of $45 \mu \mathrm{g}$ of venom protein. Infiltration of eosinophils and ruptures of the cellular membranes were observed in the muscles along with swelling of the nuclear cover and interruption of the collagen periodicity. Altered mitochondrias and autophage vacuoles, nuclear indentation and mitochondria without cristae, slight increment of intermyofibrillar and subsarcolemic spaces and myelinic figures formation were also observed. In the capillary, endothelial membrane unfolding into the lumen was noticed; along with myelinic figures compatible with a toxic myopathy. Swollen sarcotubular systems with lysis of membrane, intense mitochondria autophagia and areas without pinocytic vesicles were observed. Swollen mitochondria surrounded by necrotic areas, myofibrillar disorganization and big vacuolas of the sarcotubular system, degenerated mitochondrium with formation of myelinic figure was seen. Glycogenosomes with small particulate, muscle type glycogen was noticed. Autophagic vacuole (autophagolysosomes) and necrotic areas were also noticed. These damages may be due to interactive effects of the multifactorial action of venom components. However, Latrodectus geometricus venom molecules may also be utilized as neuro therapeutic tools, as they affect neuronal activities with high affinity and selectivity. To our knowledge, the present study is the first ultrastructural report in the literature of muscle injuries and neurological and proteolytic activities caused by BrWSV.
\end{abstract}

KEYWORDS: Latrodectus geometricus; Muscle; Neurotoxic; Ultrastructure; Venom.

\section{INTRODUCTION}

The genus Latrodectus Walckenaer 1805 (Araneae: Theridiidae) includes a group of species usually designated as black widow spiders with a global distribution and comprises approximately 30 described species, identified by the intense effectiveness of their neurotoxic actions. In Venezuela, a number of components of the genus lives in humanaltered conditions (synanthropic) and are gradually seen more in new geographical areas of the Country, possibly due to human migrations ${ }^{19}$. Latrodectus spiders are common predators of insects, arachnids and small vertebrates, which include geckos, snakes, lizards, and mice ${ }^{4}$. Venom of this genus is notorious for its most important component, $\alpha$-latrotoxin, that activates substantial neurotransmitter discharge when injected in mammals ${ }^{1}$. This toxin acts at nerve terminals by forming cation pores in the cell membranes allowing a calcium influx, resulting in depolarization of nerve cells and release of neurotransmitters. Among the many genera of spiders, the genus Latrodectus is one of the most medically important, since its venom generates cramps, profuse sweating, harsh muscle pains, nausea, vomiting, hypertension, and in rare cases, death ${ }^{16-18}$.

Neurotransmitters (excitatory and inhibitory peptides) are the most common toxins in spider venom. Neurotransmitter reduction at the cholinergic nerve terminals may explain the toxic manifestations in humans and other mammals. With additional work it is expected that L. geometricus toxins with unknown actions will prove to act at several tissue targets. For instance, to our knowledge, this is the first ultrastructural description of mice muscle tissue damages triggered by $L$. geometricus venom.

\section{MATERIALS AND METHODS}

Lethality assay: The $\mathrm{LD}_{50}$ values of $L$. geometricus venom was determined by intramuscular injections $(1.5,2.5,4.5$ and $7.4 \mu \mathrm{g})$ of mice (18-22 g) and calculated according to the SPEARMAN-KÄRBER method $^{25}$. Four mice were used at each dose level. 


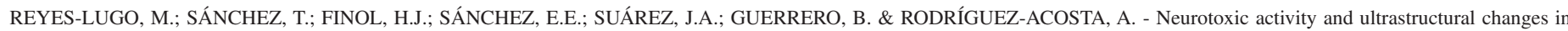
muscles caused by the brown widow spider Latrodectus geometricus venom. Rev. Inst. Med. trop. S. Paulo, 51(2): 95-101, 2009.

Venoms and animals: The spiders used in this study were collected from El Hatillo, Miranda State, Venezuela and kept in the Medical Entomology Section "Pablo Anduze" at the Tropical Medicine Institute of the Universidad Central de Venezuela, regarding the international and the Venezuelan fauna protection laws. Brown widow spider venom (BrWSV) gland extract was prepared from the females. Venom glands were dissected from frozen spiders through the cephalothoraxes and a sagittal incision was done amid their eyes. The complete venom gland of each spider was detached via chelicerae articulation and homogenized in cold lysis buffer $(25 \mathrm{mM}$ Tris/HCl, $100 \mathrm{mM} \mathrm{NaCl}$, and $\mathrm{pH}$ 8.0). The crude extract was cleared by centrifugation (20 min, $15,000 \mathrm{~g})$ and assayed for biological activity using BALB/c mice (18-22 g) from the Animal House of the National Institute of Hygiene "Rafael Rangel", Venezuela.

SDS-PAGE analysis: Polyacrylamide gel (12.5\%) electrophoresis under reducing and non reducing conditions were carried out following the LAEMMLI method ${ }^{10}$ using a Mini-Protean II system (Bio-Rad Laboratories, Hercules, CA). Molecular mass markers (Bio-Rad) were run in parallel. Venom samples were diluted in $0.063 \mathrm{M}$ Tris- $\mathrm{HCl}$ buffer, pH 6.8, containing $2 \%$ SDS, $5 \%$ glycerol and $0.001 \%$ bromophenol blue and then boiled for four min before electrophoresis at $100 \mathrm{~V}$ (constant). After electrophoresis, the gels were stained with $0.1 \%$ brilliant blue Coomassie R250 in acetic acid/ethanol/water (5:25:70, v/v) and then destained in the same solution. The molecular mass was determined by Multi-Analyst TM/PC version 1.1 software (Bio-Rad).

Neurotoxic activity: To establish the neurological symptomatology produced by the venom, six mice were subcutaneously injected with $100 \mu \mathrm{L} \mathrm{BrWSV}$ (45 $\mu \mathrm{g} / 20 \mathrm{~g}$ of mouse weight), and were observed for neurotoxic effects for a period of $19 \mathrm{~h}$.

Gelatinase assay: A modified method ${ }^{14}$ was used to assay the gelatinase activity of L. geometricus BrWSV. An X-ray film (Kodak $\mathrm{X}$-OMAT) was washed with distilled water and incubated at $37{ }^{\circ} \mathrm{C}$ for $45 \mathrm{~min}$. After incubation, the film was completely dried and $10 \mu \mathrm{L}$ of a series of dilutions of BrWSV (starting concentraion of $7.2 \mathrm{mg} / \mathrm{mL}$ ) were placed on the x-ray scientific imaging film containing a gelatine coating to determine the minimum amount of venom required to still cause a clear area. The hydrolysis of gelatine on the x-ray film was determined after three $\mathrm{h}$ incubation at $37^{\circ} \mathrm{C}$ in a humid incubator by washing the $\mathrm{x}$-ray film with distilled water. The assay was repeated three times.

Preparation of specimens for electron microscopy: Adult male mice were divided into two groups: control mice, which were intraperitoneally (i.p) injected with $0.1 \mathrm{~mL}$ of saline solution and treated mice, which were injected i.p. with $45 \mu \mathrm{g}$ of BrWSV in $200 \mu \mathrm{L}$ of PBS. After 3, 6, 12 and $24 \mathrm{~h}$, mice were removed from the cages and prepared for muscle biopsies.

Sartorius muscle biopsies were obtained from control and experimental mice under anaesthesia at 3, 6, 12 and $24 \mathrm{~h}$. Samples were immediately in situ fixed with $3 \%$ glutaraldehyde and $1 \% \mathrm{OsO}_{4}$ (both fixatives diluted in $320 \mathrm{mM}$ phosphate buffer saline, $\mathrm{pH}$ 7.4), dehydrated in ethanol and embedded in LX-112 resin (Ladd Research Inc.). Ultrathin sections were stained with uranyl acetate and lead citrate and observed by a Hitachi HS-500 transmission electron microscope with an accelerating voltage of $100 \mathrm{kV}$.

\section{RESULTS}

Lethality: The $\mathrm{LD}_{50}$ for L. geometricus BrWSV was determined to be $4.5 \mu \mathrm{g}$ protein $/ 20 \mathrm{~g}$ of mouse body weight $(0.225 \mathrm{mg} / \mathrm{kg})$.

Sodium dodecyl sulfate-polyacrylamide gel electrophoresis: The $12.5 \%$ SDS PAGE revealed $\sim 16$ protein bands under reducing conditions and $\sim 14$ bands under non-reducing conditions (Fig. 1). The gel was visualized with silver stain.

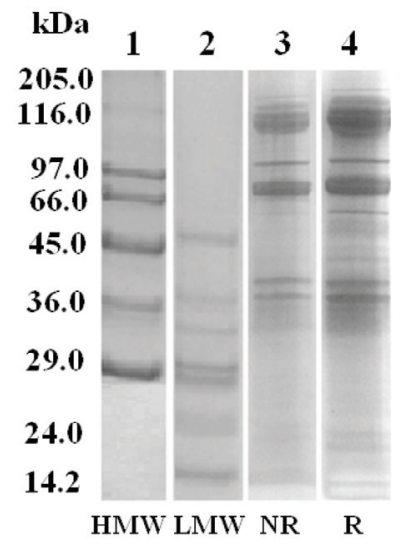

Fig. 1 - 12.5\% SDS-PAGE of L. geometricus venom. HMW: high molecular weight markers. LMW: low molecular weight markers. NR: L. geometricus venom under non-reducing conditions. R: L. geometricus venom under reducing conditions.

Neurotoxic activity: Latrodectus geometricus BrWSV neurotoxic activity was demonstrated by the neurological symptoms experienced in mice injected subcutaneously with this venom (Table 1). A total of six mice were used to determine the BrWSV effects. Each mouse was assigned a number (1-6) and observed for various effects at different times until death occurred. The symptomatology for every animal during the experiment appears for the duration of the survival for every mouse. For instance, one exhibited pain at $15 \mathrm{~min}$ followed by bradypnea at $140 \mathrm{~min}$, muscle twitch, sphincter relaxation and apnea at $200 \mathrm{~min}$, subsequently dying. Controls injected with saline solution survived without any apparent symptomatology.

Gelatinase activity: The minimal amount of BrWSV venom protein capable of causing gelatinase activity was $9 \mu \mathrm{g}$.

Transmission electron microscopy (TEM): A normal muscle control of a mouse after $24 \mathrm{~h}$ post injected with saline solution was analyzed by TEM. Given the tissue-striated pattern, regular arrangements of sarcomeres within the myofibrils with a normal display of mitochondria were observed (Fig. 2).

In samples from mice injected with venom, electron microscopy figures showed muscular tissue with lesions characterized by eosinophil infiltrates after three hours. These cells presented many dense granules, which did not allow the observation of the "central lattice cristaloid" (extremely alkaline major basic protein). Several ruptures of the cellular membrane were observed. The nuclear cover was swollen and there was an interruption of the collagen periodicity. Altered mitochondria and autophagic vacuole were also observed (Fig. 3A). An interruption of 
REYES-LUGO, M.; SÁNCHEZ, T.; FINOL, H.J.; SÁNCHEZ, E.E.; SUÁREZ, J.A.; GUERRERO, B. \& RODRÍGUEZ-ACOSTA, A. - Neurotoxic activity and ultrastructural changes in muscles caused by the brown widow spider Latrodectus geometricus venom. Rev. Inst. Med. trop. S. Paulo, 51(2): 95-101, 2009.

Table 1

Chronological neurological manifestations of mice injected with $45 \mu \mathrm{g}$ of Latrodectus geometricus venom

\begin{tabular}{|c|c|c|c|c|c|c|c|}
\hline Time (min) & Bradypnea & Muscle twitch & Pain (squealing) & Diarrhea & Urinary sphincter relaxation & Apnea & Death \\
\hline 15 & & & $1,2,4,6$ & & & & \\
\hline 90 & & $5,4,6$ & 5 & & & & \\
\hline 140 & $1 *, 3$ & & & 2 & & & \\
\hline 200 & $2,5,6$ & $1,3,4$ & & 5 & 1,4 & $1,3,4$ & $1,3,4$ \\
\hline 280 & & & & & 2,5 & 5,6 & $5,2,6$ \\
\hline
\end{tabular}

* A total of six mice were used to determine the effects of BrWSV. Each mouse was assigned a number (1-6) and observed for various effects at different times until death occurred.

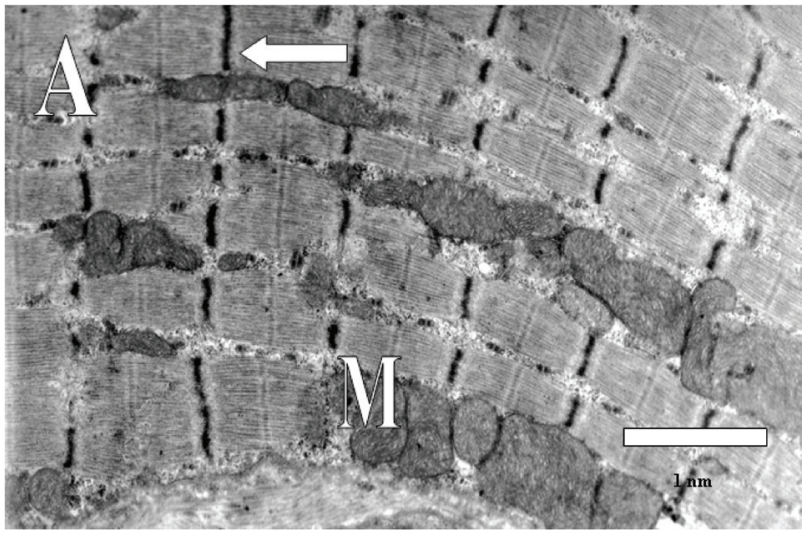

Fig. 2 - Analysis of transmission electron micrographs (TEM) of normal mouse muscle (control) after $24 \mathrm{~h}$ of an intraperitoneal saline solution injection. The magnification analysis viewing the main cellular components showed regular arrangements of sarcomeres within the myofibrils given the tissue striated patterns (arrow) with a normal display of mitochondria (M). (Bar=1 nm). (X 26,000).

the collagen periodicity in some intracellular fields was seen. Limitant membrane loss was noticed along with a nuclear indentation and mitochondria without cristae (Fig. 3B).

At six hours, electron microscopy figures demonstrated a slight increment of intermyofibrillar and subsarcolemic spaces. Myelinic figure formations (probably from mitochondria) and glycogen disappearance, for which free polysomas become evident, were seen. In the capillary, endothelial membrane unfolding into the lumen was noticed (Fig. 4C). Capillary with pinocytic vesicles and caveol loss were observed. Endothelium swelling and unfolding to the lumen were noticed. Vacuoles in endothelial cells and autophagic vacuola were also seen (Fig. 4D).

At $12 \mathrm{~h}$, electron microscopy figures showed myelinic figures compatible with a toxic myopathy. Nuclear indentations with dilated envelopes (Fig. 5E) were observed. Slight swelling of the sarcotubular system was also observed. A slightly swollen mitochondria and myelinic figure was noticed (Fig. 5F). Mitochondria autophagia, swollen sarcotubular systems with lysis of membranes, and myofibrils with total organization and disposition loss were noticed (Fig. 6G). In addition, intense mitochondria autophagia and areas without pinocytic vesicles

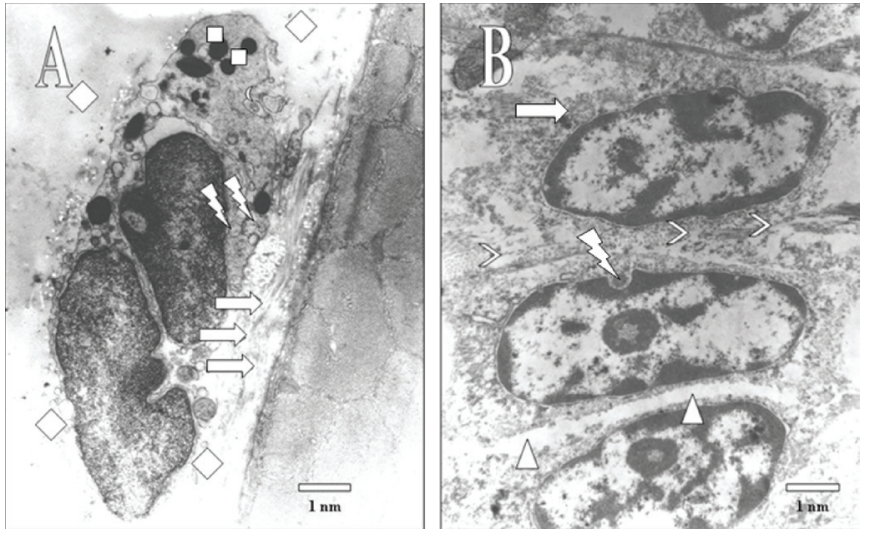

Figs. 3A and B - Analysis of TEM of muscular tissue after $3 \mathrm{~h}$ of an i.p injection of venom. A) The muscle contained lesions characterized by eosinophil infiltrates. These cells presented many dense granules (squares), which did not allow the observation of the "central lattice cristaloid". Several ruptures of the cellular membrane were observed (rhombus). The nuclear cover was swollen (circle) and there was an interruption of the collagen periodicity (arrows). Altered mitochondria and autophagic vacuole were also observed (rays). (Bar $=1 \mathrm{~nm})$. (X 20,000). B) The tissue presented lesions characterized by an interruption of the collagen periodicity (arrowheads) in some intracellular fields. Limitant membrane loss (triangle) was noticed. Nuclear identation (ray) and mitochondria without cristae (arrow) were observed. $(\mathrm{Bar}=1 \mathrm{~nm})$. (X 30,000).

were observed. Swollen mitochondria surrounded by necrotic areas was seen. In the capillary, endothelium unfolding to the lumen was noticed (Fig. 6H). At 24 h, electron microscopy figures presented dense bodies probably originated from mitochondria. Myofibrillar disorganization and big vacuoles of the sarcotubular system were observed (Fig. 7I). Degenerated mitochondrium with formation of myelinic figure was seen. Glycogenosomes with small particulate, muscle type glycogen was observed. Autophagic vacuoles (autophagolysosomes) and necrotic areas were noticed (Fig. 7J).

\section{DISCUSSION}

Brown widow spiders control the magnitude of venom they inject using striated muscle, which forces the glands and inoculates venom into the prey. Latrodectus attacks do not inevitably signify envenomation. It is expected that $15 \%$ of bites in victims are dry ${ }^{9}$. The venom of the BrWSV contains a number of biological active toxins. The most important is a 


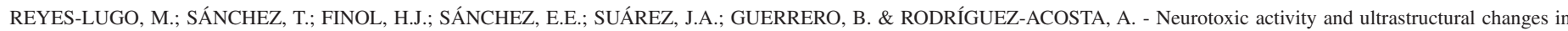
muscles caused by the brown widow spider Latrodectus geometricus venom. Rev. Inst. Med. trop. S. Paulo, 51(2): 95-101, 2009.
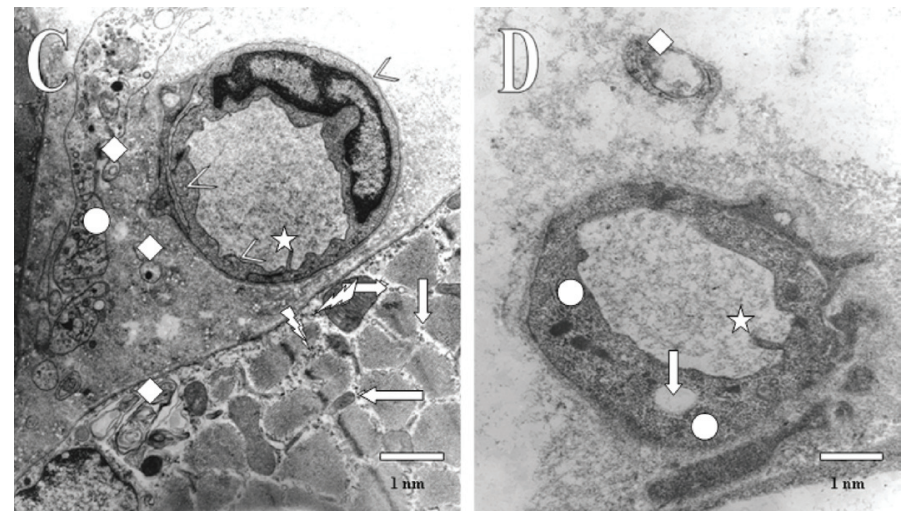

Figs. 4C and D - Analysis of TEM of muscular tissue after $6 \mathrm{~h}$ of an i.p venom injection. C) The tissue demonstrated slight increment of intermyofibrillar and subsarcolemic spaces (arrows). Myelinic figure formations (probably from mitochondria) (rhombus) and glycogen disappearance, for which free polysomas (rays) become evident, were seen. In the capillary, endothelial membrane unfolding into the lumen (star) was noticed. A macrophage (circle) was noticed. The capillary vessel contained a continuous rather than a fenestrated endothelium, and pinocytic vesicles and caveols loss (arrowhead) were seen. (Bar = $1 \mathrm{~nm})$. (X 20,000). D) The tissue demonstrated endothelium swelling (circle) and unfolding to the lumen (star). Vacuoles in endothelial cells (arrow) and autophagic vacuola (rhombus) were seen. Capillary with pinocytic vesicles and caveols loss was also noticed. (Bar = $1 \mathrm{~nm})$. (X 20,000).
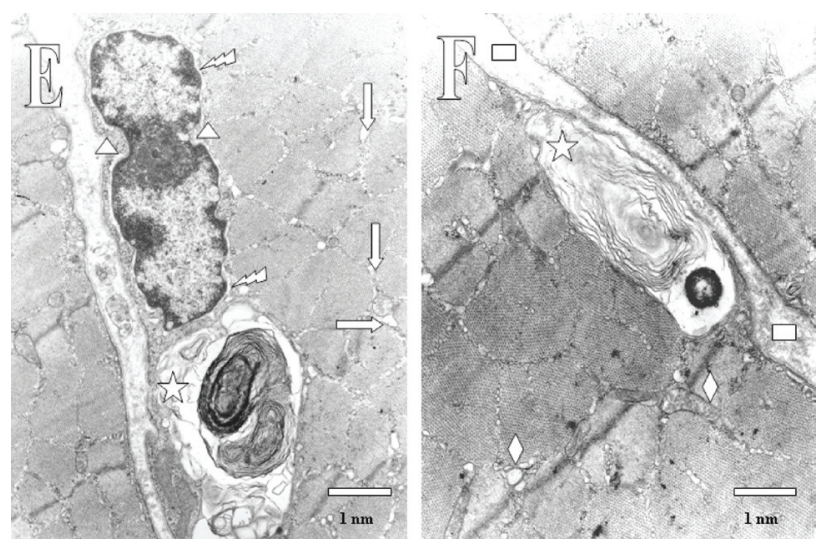

Figs. 5E and F - Analysis of TEM of muscular tissue after $12 \mathrm{~h}$ of an i.p venom injection. E) The tissue showed a myelinic figure (star) compatible with a toxic myopathy. Nuclear identations (triangles) with dilated envelopes (rays) were observed. Slight increments of intermyofibrillar and subsarcolemic spaces (arrows) were also noticed. (Bar = $1 \mathrm{~nm}) .(X 30,000)$. F) The tissue demonstrated mild swelling of the sarcotubular system (rectangles). A slightly swollen mitochondria (rhombus) and myelinic figure (star) was noticed. (Bar = $1 \mathrm{~nm})$. (X 30,000).

neurotoxin described as $\alpha$-latrotoxin that provokes neurotransmitter discharge from nerve terminals. This neurotoxin promotes little end-plate action potentials, but eventually produces a blockade in neurological transmission, mainly by depletion of synaptic vesicles within the neuromuscular junction ${ }^{10}$.

Neurotoxins described from spider venoms are classified in agreement with their activities: toxins affecting glutamatergic transmission, calcium, sodium, potassium and chloride channel toxins, toxins that stimulate transmitter release and toxins blocking postsynaptic cholinergic receptors ${ }^{13}$.
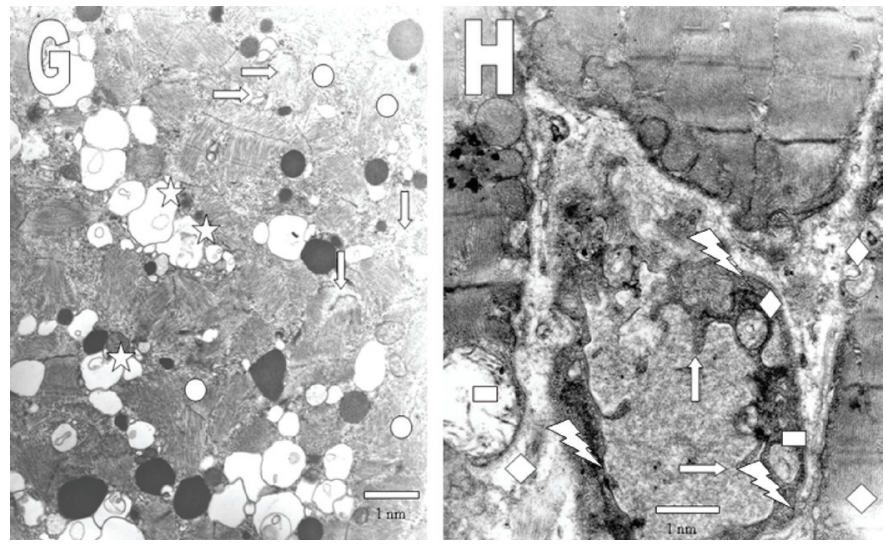

Figs. 6G and H - Analysis of TEM of muscular tissue after $12 \mathrm{~h}$ of an i.p venom injection. G) The tissue showed mitochondria autophagia (arrows), swollen sarcotubular systems with lysis of membranes (stars), and myofibrils with total organization and disposition loss (circles). (Bar $=1 \mathrm{~nm}) .($ X 20,000). H) The tissue contained intense mitochondria autophagia (rectangles) and areas without pinocytic vesicles (rays). Swollen mitocondria (rhombus) surrounded by necrotic areas was also seen. In the capillary, endothelium unfolding to the lumen (arrow) was noticed. (Bar = $1 \mathrm{~nm})$. (X 20,000).
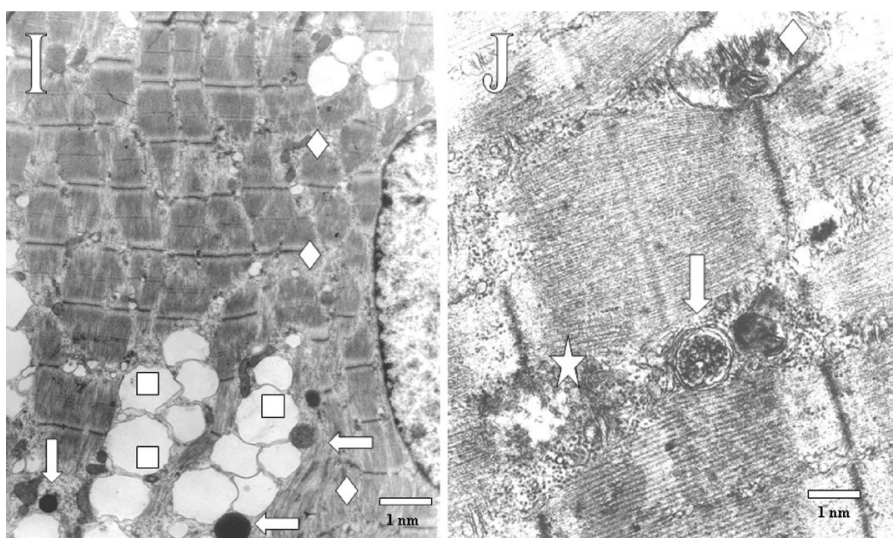

Figs. 7I and J - Analysis of TEM of muscular tissue after $24 \mathrm{~h}$ of an i.p venom injection. I) The tissue presented dense bodies probably originated from mitochondria (arrows). Myofibrillar disorganization (rhombus) and big vacuolas of the sarcotubular system (squares) were observed. (Bar $=1 \mathrm{~nm}$ ). (X 20,000). J) The tissue showed degenerated mitochondrium with formation of a myelinic figure (rhombus). Glycogenosomes with small particulate muscle type glycogen (arrow) was observed. Autophagic vacuole (autophagolysosomes) and a necrotic area (star) were noticed. (Bar $=1 \mathrm{~nm})$. (X 20,000).

Regarding neurotoxic activities in the present study, mice were particularly vulnerable to BrWSV. In our experiment all mice died following BrWSV injections with a final survival time of $280 \mathrm{~min}$ postinjection. Neurological disorders became visible $1.5 \mathrm{~h}$ after injections and were highly obvious due to the spastic muscle twitching, most likely caused by massive release of neurotransmitters, changes in ion channels and inhibition of vesicle recycling ${ }^{29}$. Aside from the high molecular weight latrotoxins $(\sim 130 \mathrm{kDa})$, Latrodectus venom also contains low molecular weight peptides ${ }^{5}$, whose roles have not been studied entirely thus far, but may be implicated in assisting membrane incorporation of latrotoxins. Alternatively, harsh pain was manifested by a squealing 


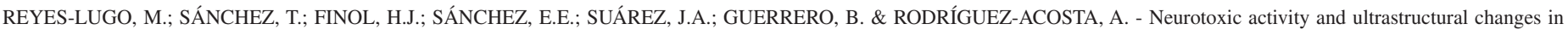
muscles caused by the brown widow spider Latrodectus geometricus venom. Rev. Inst. Med. trop. S. Paulo, 51(2): 95-101, 2009.

sound. After injections, the mice appeared to be irritable, aggressive and conducted repetitive "face washing" (a mouse may wash its face continually if it feels insecure). This was followed by syalorrhea, agitation, vomiting and diarrhea. The syalorrhea lacrimation and diarrhea seemed to indicate that the neurotoxin(s) of L. geometricus venom have muscarinic effects. Muscular fibrillations, contractions and ataxia were also noticed. This situation turned adynamic and atonic and the inability to move proceeded by total paralysis. Finally, a Cheyne-Stokes respiratory symptom appeared, and death proceeded, which probably was due to dysfunctions at the neuromuscular junction level ${ }^{13}$.

Besides the neurotoxins that are very well described in spider venoms, spider venoms also contain metalloproteinases that give rise to severe dermo- and myonecrosis. Matrix metalloproteinases have gelatinase activity as extensively described by ZHAO et al. (2007) $)^{31}$. The BrWSV's proteolytic activity was established using gelatine, for the purpose of determining collagenase activity. The minimal gelatinase dose (MGD) of BrWSV venom still capable of producing a clear area on an X-ray film was $9 \mu \mathrm{g}$. This venom is slightly more gelatinous than the venom of the Malayan pit viper (Calloselasma rhodostoma), which required a minimum dose of $13 \mu \mathrm{g}^{21}$. The BrWSV activity is also comparable to Leptodeira bakeri, a "non-venomous" colubrid, with a minimal gelatinose dose (MGD) of $5 \mu \mathrm{g}$ (ESTRELLA et al., personal communication). However, none of the gelatinase activities of these venoms are compared to the activity of the venom from the Philodryas olfersii ("non-venomous"), which had an MGD of $0.3 \mu \mathrm{g}^{22}$. Taking into consideration the role of MMP in tissue damage and remodelling, despite that several of the described myotoxic toxins are phospholipases ${ }^{26,30}$, we have suspected the probable participation of these proteases (MMP) in the progression of the muscle lesions in our current study. Matrix metalloproteinases (MMPs), a family of proteinases including collagenases, gelatinases, stromelysins, matrilysins, and membrane-type MMPs, affect the breakdown and turnover of extracellular matrix (ECM) ${ }^{11}$. Gelatine is vulnerable to a majority of proteases, and it is derived from sources rich in Type I collagen which contains no cysteines ${ }^{2}$. The presence of collagenase activity in BrWSV is an interesting finding since collagenases are extremely specific in their function, spliting the triple helix of fibrillar collagens ${ }^{3}$. Collagenase is a common molecule present in many snake venoms ${ }^{15,22}$. The spreading property of these enzymes are not well known, but degradation of collagen leads to the failure of the integrity of the extracellular matrix in capillary vessels, which may facilitate and support the rapid dispersion of these toxins to the targeted tissues during spider envenomation. Even though collagenases such as hyaluronidases probably enhance venom activities by increasing the dispersion of toxins, these enzymes have been basically unobserved in venoms of animals.

There are many toxins found in spider venoms that synergistically play a role in acute morphological changes in muscles. In other spiders, such as those from the genus Loxosceles, the injection of their venom suggested that tissue injury is aggravated by leukocyte infiltration (including eosinophils) and deposition of complement component C3. Reduction of complement by cobra venom factor was able to postpone, but not restrain, the Loxosceles venom-induced tissue damage in the work of TAMBOURGI et al. (2005) $)^{27}$. These findings not only imply essential functions for leukocytes and complement in the tissue pathogenesis of loxoscelism, but also prove that other causes are involved. Inflammatory reactions are characterized by emigration of leukocytes to chemotactic stimuli and the subsequent release of intracellular enzymes such as collagenases, which propagate the inflammatory reaction and further contribute to tissue damages ${ }^{20}$. The precise mechanisms of these actions in the pathology of latrodectism require further explanation.

Fig. 3A shows eosinophils infiltrated in muscle that can release toxins causing pain, inflammation, erosion, and damage in the affected tissue. The autophagic activity (Figs. 3A, 4D and 6H) by the degradation of intracellular components via the lysosome is the most common autophagic process involving the creation of a membrane just below the targeted region of the cell, untying the inside from the remaining cytoplasm. The resultant vesicle then fuses with a lysosome and afterward disintegrates the inside ${ }^{28}$. In addition, when tissues are damaged, cells release their enzymes, which digest both damaged and healthy cells.

It has been considered that the cellular damage inhibitory effect of toxins on metabolism enzymes could lead to the enlargement of glycogen particles, and the large glycogen molecules can then be engulfed in the lysosome system producing glycogenosomes such as those reported by HAMADA et al. ${ }^{7}$ in metal intoxications and also those observed in the current work (Fig. 7J).

Normally, nuclei are spherical, elongated, or lobed, depending on the cell type, but are not indentated such as that observed in the present work (Fig. 5E). Normally, the nucleus is surrounded by a nuclear envelope, and can be damaged by toxins, which is a stepwise progression that involves chronological lamina disassembly and microtubule-driven deformation of the nuclear membrane ${ }^{6}$.

After three hours of venom injection, mitochondria ultrastructural alterations in most of the muscles were found. Mitochondria are usually small, rod-shaped structures, but under different toxin activities they can be heavily damaged, changing their normal morphology (Figs. 3B, 4C, $6 \mathrm{G}, 6 \mathrm{H}$ ) and function ${ }^{8,23,24}$. The formation of myelin figures observed in the cytoplasm of muscle cells (Figs. 4C, 7J) were possibly due to degradation or hydration of lipoprotein of self-digested organelles, mainly mitochondria.

For many years, Latrodectus spiders have been incriminated in causing serious afflictions in humans, rendering their venom medically significant. These spider bites occur worldwide and cause a symptom known as latrodectism, which is described by pain (restricted and generalized), linked with imprecise systemic actions, and less common, autonomic and neurological effects. In spite of the adverse reactions caused by BrWSV, L. geometricus venom molecules may also be used as neuro-therapeutic tools, as they link neurons with high affinity and selectivity. Target neurons can be used to express transgenes to alter the structure and/or function of the nervous system. The stage is set for the use of these neurotoxin-based vectors in the near future to treat neurologic diseases in humans, such as causes of neuronal function (pain), neurodegeneration (Parkinson's disease), and peripheral neuropathy. To our knowledge, this current study is the first ultrastructural description of muscle damages and neurological and proteolytic activities caused by BrWSV.

\section{ETHICAL STATEMENT}

The persons behind the experiments declare that all the experimental events concerning the use of live animals were done by specialized personnel following the Venezuelan pertinent regulations as well as 
REYES-LUGO, M.; SÁNCHEZ, T.; FINOL, H.J.; SÁNCHEZ, E.E.; SUÁREZ, J.A.; GUERRERO, B. \& RODRÍGUEZ-ACOSTA, A. - Neurotoxic activity and ultrastructural changes in muscles caused by the brown widow spider Latrodectus geometricus venom. Rev. Inst. Med. trop. S. Paulo, 51(2): 95-101, 2009.

institutional guidelines, according to protocols approved by the Tropical Medicine Institute of the Universidad Central de Venezuela Comission of Ethics and the norms obtained from the guide for the care and use of laboratory animals, published by the US National Institute of Health (Anonymous 1985).

\section{RESUMEN}

\section{Actividad neurotóxica y cambios ultraestructurales en musculos causados por el veneno de la araña viuda marrón Latrodectus geometricus}

El veneno de la araña viuda marrón (Latrodectus geometricus) produce pocas lesiones locales pero intensas reacciones sistémicas, tales como calambres, dolores musculares severos, nauseas, vómitos e hipertensión arterial. Se observaron $\sim 16$ bandas de proteina bajo condiciones reducidas $\mathrm{y} \sim 14$ bandas bajo condiciones no reducidas en electroforesis en geles de poliacrilamida al $12.5 \%$. Las manifestaciones neurotóxicas clínicas fueron confirmadas in vivo, mientras que la actividad proteolítica fue demostrada en una placa de gelatina. Los músculos de ratón se estudiaron durante las 3 , 6,12 y 24 horas después de ser inyectados con $45 \mu \mathrm{g}$ de proteina de veneno. Los músculos fueron seriamente dañados por este veneno. Se demostró una infiltracción de células eosinofílicas y rupturas de membranas celulares en tejido muscular, al mismo tiempo un fuerte incremento de la membrana nuclear y una interrupción de la periodicidad del colágeno. Se observaron daños en la mitocondria y sin cristaes, vacuolas autofágicas e indentación nuclear. Se notó un aumento de la luz de los espacios intermiofibrilares y subsarcolemicos. En los capilares fue visible un desdoblamiento de la membrana endotelial hacia el lúmen vascular. Del mismo modo, fue visto un hinchamiento del sistema sarcotubular con lisis de las membranas; intensa autofagia de mitocondrias y áreas sin vesículas pinocíticas. Fue además observado, glucogenosomas con glucogeno particulado. Se observaron vacuolas autofágicas (autofagolisosomas) y áreas de necrosis. Estos daños podrían ser atribuídos a los efectos interactivos de una acción multifactorial de los componentes del veneno.

\section{REFERENCES}

1. ASHTON, A.C.; RAHMAN, M.A.; VOLYNSKI, K.E. et al. - Tetramerisation of alphalatrotoxin by divalent cations is responsible for toxin-induced non-vesicular release and contributes to the $\mathrm{Ca}(2+)$-dependent vesicular exocytosis from synaptosomes. Biochimie, 82: 453-468, 2000.

2. BAILEY, A.J. \& KENT, M.J. - Non-enzymatic glycosylation of fibrous and basement membrane collagens. Prog. clin. biol. Res., 304: 109-122, 1989.

3. BARRICK, B.; CAMPBELL, E.J. \& OWEN, C.A. - Leukocyte proteinases in wound healing: roles in physiologic and pathologic processes. Wound Repair Regen., 7: 410-422, 1999 .

4. FORSTER, L.M. - The behavioral ecology of Latrodectus hasselti (Thorell), the Australian redback spider (Araneae: Theridiidae): A review. Rec.West. Aust. Mus, 52: 13-24, 1995.

5. GASPARINI, S.; KIYATKIN, N.; DREVET, P. et al. - The low molecular weight protein which co-purifies with alpha-latrotoxin is structurally related to crustacean hyperglycemic hormones. J. biol. Chem., 269: 19803-19809, 1994.

6. GEORGATOS, S.D.; PYRPASOPOULOU, A. \& THEODOROPOULOS, P.A. - Nuclear envelope breakdown in mammalian cells involves stepwise lamina disassembly and microtubule-driven deformation of the nuclear membrane. J. Cell Sci., 110: 21292140, 1997.
7. HAMADA, T.; IWAMASA, T.; TSURU, T.; SATO, K. \& TAKEUCHI, T. - Mechanism of glycogenosome formation in axons of cadmium-induced neuropathy--ultrastructural and biochemical studies. Neurotoxicology, 2: 33-41, 1981.

8. HERNÁNDEZ, M.; SCANNONE, H.; FINOL, H.J. et al. - Alterations in the ultrastructure of cardiac autonomic nervous system triggered by crotoxin from rattlesnake (Crotalus durissus cumanensis) venom. Exp. Toxicol. Path., 59: 129-137, 2007.

9. KEY, G.F. - A comparison of calcium gluconate and methocarbamol in the treatment of Latrodectism (black widow spider envenomation), Amer. J. trop. Med. Hyg , 30: 273-277, 1981.

10. KNIPPER, M.; MADEDDU, L.; BREER, H. \& MELDOLESI, J. - Black widow spider venom-induced release of neurotransmitters: mammalian synaptosomes are stimulated by a unique venom component ( $\alpha$-latrotoxin), insect synaptosomes by multiple components. Neuroscience, 19: 55-62, 1986.

11. KRANE, S.M. \& INADA, M. - Matrix metalloproteinases and bone. Bone, 43: 7-18, 2008.

12. LAEMMLI, U.K. - Cleavage of structural proteins during the assembly of the head of bacteriophage T4. Nature, 227: 680-685, 1970.

13. LARRECHE, S.; MION, G.; CLAPSON, P. et al. - Neurotoxins from snake venom. Ann. français. Anesth. Reanim, 27: 310-316, 2008.

14. LEMOINE, K.; GIRÓN, M.E.; AGUILAR, I.; NAVARRETE, L.F. \& RODRÍGUEZACOSTA A. - Proteolytic, hemorrhagic, and neurotoxic activities caused by Leptodeira annulata ashmeadii (Serpentes: Colubridae) Duvernoy's gland secretion. Wildern. environ. Med., 15: 82-89, 2004.

15. LEMOINE, K. \& RODRÍGUEZ-ACOSTA, A. - Hemorrhagic, proteolytic and neurotoxic activities produced by Duvernoy's gland secretion from the false coral snake (Erythrolamprus bizona Jan 1863) (Serpentes: Colubridae). Rev. cient. FCV-LUZ, 13: 371-377, 2003

16. MACHADO, A. \& RODRÍGUEZ-ACOSTA A. - Animales venenosos y ponzoñosos de Venezuela. Caracas, Consejo de Desarrollo Cientıfico y Humanıstico de la Universidad Central de Venezuela, 2005.

17. MARETIC, Z. - Latrodectism: variations in clinical manifestations provoked by Latrodectus species of spiders. Toxicon, 21: 457-466, 1983.

18. MÜLLER, G.J. - Black and brown widow spider bites in South Africa. A series of 45 cases. S. Afr. med. J., 83: 399-405, 1993.

19. ORI, M.; SHINKAI, E.I. \& IKEDA, H. - Introduction of widow spiders into Japan. Med. Ent. Zool., 47: 111-119, 1996.

20. PERPER, R.J. - Mechanisms by which leukocytes emigrate and induce tissue destruction. Agents Actions, 6: 232-242, 1976.

21. PORNMANEE, P.; SANCHEZ, E.E.; LOPEZ, G. et al. - Neutralization of lethality and proteolytic activities of Malayan pit viper (Calloselasma rhodostoma) venom with North American Virginia opossum (Didelphis virginiana) serum. Toxicon, 52: 186189,2008

22. RODRÍGUEZ-ACOSTA, A.; LEMOINE K.; NAVARRETE, L.; GIRÓN, M. \& AGUILAR, I. - Experimental ophitoxemia produced by the opisthoglyphous Lora snake (Philodryas olfersii) (Serpentes: Colubridae) venom. Rev. Soc. bras. Med. trop., 39: 193-197, 2006.

23. RODRIGUEZ-ACOSTA, A.; STRAUSS, M.; PULIDO-MENDEZ, M. \& FINOL, H.J. - Adrenal gland ultrastructural changes in mice inoculated with Tityus discrepans (Buthidae) venom. Rev. cient. FCV-LUZ, 10: 480-485, 2000.

24. RODRIGUEZ-ACOSTA, A.; PEÑA, L.; FINOL, H.J. \& PULIDO-MENDEZ, M. - Cellular and subcellular changes in muscle, neuromuscular junctions and nerves caused by bee (Apis mellifera) venom. J. Sub. Cytol. Path., 36: 91-96, 2004. 
REYES-LUGO, M.; SÁNCHEZ, T.; FINOL, H.J.; SÁNCHEZ, E.E.; SUÁREZ, J.A.; GUERRERO, B. \& RODRÍGUEZ-ACOSTA, A. - Neurotoxic activity and ultrastructural changes in muscles caused by the brown widow spider Latrodectus geometricus venom. Rev. Inst. Med. trop. S. Paulo, 51(2): 95-101, 2009.

25. SPEARMAN, C. \& KARBER, G. - Alternative methods of analysis for quantal response. In: FINNEY, D.J., ed. Statistical methods in biological assays. London, Charles Griffin, 1978.

26. STERNLICHT, M.D.; BISSELL, M.J. \& WERB, Z. - The matrix metalloproteinase stromelysin-1 acts as a natural mammary tumor promoter. Oncogene, 19: 1102-1113, 2000

27. TAMBOURGI, D.V.; PAIXÃO-CAVALCANTE, D.; GONÇALVES DE ANDRADE, R.M. et al. - Loxosceles Sphingomyelinase induces complement-dependent dermonecrosis, neutrophil infiltration, and endogenous gelatinase expression. J. invest. Derm., 124: 725-731, 2005.

28. TSUJIMOTO, Y. \& SHIMIZU, S. - Another way to die: autophagic programmed cell death. Cell Death Differ, 12: 1528-1534, 2005.
29. VETTER, R.S. \& VISSCHER, P.K. - Bites and stings of medically important venomous arthropods. Int. J. Derm., 37: 481-496, 1998.

30. VILLALOBOS, J.C.; MORA, R.; LOMONTE, B.; GUTIÉRREZ, J.M. \& ANGULO, Y. - Cytotoxicity induced in myotubes by a Lys49 phospholipase A2 homologue from the venom of the snake Bothrops asper: evidence of rapid plasma membrane damage and a dual role for extracellular calcium. Toxicol. in vitro, 21: 1382-1389, 2007.

31. ZHAO, J.X.; YANG, L.P.; WANG, Y.F. et al. - Gelatinolytic activity of matrix metalloproteinase-2 and matrix metalloproteinase-9 in rat brain after implantation of 9L rat glioma cells. Europ. J. Neurol., 14: 510-516, 2007.

Received: 16 August 2008

Accepted: 19 January 2009 